\title{
デート DVの実態の検討（1）
}

一恋人との関係における否定的側面の観点から-

○竹澤みどり ${ }^{1}$ ・ 寺島睲 ${ }^{2} \cdot$ 宮前淳子 $^{3}$ ・宇井美代子 ${ }^{4}$ ・松井めぐみ ${ }^{5}$

( 1 富山大学・ ${ }^{2}$ 筑波大学・ 3 香川大学・ 4 東京福禅大学・ 5 岡山大学 $)$

キーワード: デート DV, 恋人関係, 学生

\begin{abstract}
A study of actual condition of Dating Violence (1): Approach from perspectives of negative aspects in dating relationships
Midori TAKEZAWA ${ }^{1}$, Hitomi TERASHIMA ${ }^{2}$, Junko MIYAMAE ${ }^{3}$, Miyoko UI $^{4}$ and Megumi MATSUI ${ }^{5}$

$\left({ }^{1}\right.$ Univ. of Toyama, ${ }^{2}$ Univ. of Tsukuba, ${ }^{3}$ Kagawa Univ.,${ }^{4}$ Tokyo Univ. and Graduate School of Social Welfare, ${ }^{5}$ Okayama Univ. $)$ Key words: Dating Violence, dating relationship, student
\end{abstract}

\section{目 的}

内閣府（2009）の調査によると，10 歳代から 20 歳代の頃 に，女性の $13.6 \%$, 男性の $4 \%$ が交際相手から “身体的暴行”, “心理的攻撃”, “性的強要”のいずれかをされた経験があるこ とが明らかとなっている。その他，大学生を対象とした実態 調査は行われているが，そのほとんどがデートDV と考えら れる具体的な項目を提示してその有無を問う方法で行われて いる。そのため, デート DV に当たる実際に行われている行 為が網羅されているとは言い難い。そこで, より詳細にかつ 包括的に現代の学生が交際相手からされて傷ついた・見下さ れた・怖い・嫌だと感じた行為やその対処の実態を把握する ことを目的として，自由記述調査を行うこととした。

\section{方 法}

調查対象者 : 大学生・看護専門学生 158 名（男性 28 名・女 性 126 名 $)$ 。平均年齢 19.8 歳 $(S D=1.04)$ 。

調査内容: (1)基本情報（性別, 家族との同居の有無, これま でに恋人がいた経験の有無など), (2)恋人にされて精神的・身 体的・性的に，傷ついた・見下された・怖い・嫌だなどと感 じた行為(以下，「恋人にされた行為」)，(3)その時の気持ち，(4)そ の時の対処, (5)その行為の後別れたか否か((3), (4) 今回の分析 では使用していない)。

調査手続き：授業時間に質問紙票を配布し，学生に自宅に持 ち帰り記入した後に郵送にて返送してもらった。835 名に配 布したうち 158 名から回答が得られた（回収率 18.9\%)。

調查時期 : 2010 年 1 月〜2 月。

\section{結 果 と 考 察}

全調查対象者の $51.9 \%$ （男性 22 名・女性 58 名）が一人暮 らしであり，77.2\%（男性 21 名・女性 97 名）がこれまでに 恋人がいた経験のある人（平均交際人数 2.3 人）であった。

158 名中 73 名 $(46.2 \%)$ （男性 8 名・女性 62 名・不明 3 名) が「恋人にされた行為」について記述していた。このうち, $52.1 \%$ が一人暮らしであり, これまでの交際相手の人数は平 均 3.0 人であった。また, $46.6 \%$ がこのような行為をされたの ちその相手との関係を解消していた。

全記述数は 140 であった。それらを心理学の教員 4 名によ って KJ 法を用いてカテゴリー化した。その後, 心理学の教 員 1 名と心理学を専攻する院生 3 名によってカテゴリー化の 妥当性が確認された。その結果, 17 カテゴリーが抽出された (Table 1)。「見下し」は人格の否定，説教，コンプレックスに ついての指摘などの見下したような言動,「浮気」は自分以外 の人とも付き合うなどの行為,「䃚妬・束縛」は極度の䃚妬や 頻繁なメール, 電話による行動の詮索といった行為, 「ないが しろ・放置」は冷たい態度や急に連絡が取れなくなるなどの 自分をないがしろにするような相手の行為,「性的行為の要求 は望まない身体接触や性行為, 体だけの関係を求める言動, 「第三者への気のある素振り」は自分以外の人を良く言ったり， 仲良くしたりといった行為,「約束の反故」は約束を破るなど
の行為,「怒りをぶつける」は怒鳴ったり, 八つ当たりをした りといった行為, 「趣味・主張の押し付け」は自身の趣味・好 みや意見を押し付けてくるような言動,「コントロール」は行 動や意思決定について指図したり，自傷行為によって相手を コントロールするような言動, 「関係解消」は別れをほのめか す, または求めるような言動, 「身体的暴力」は物を壊すこと も含めた暴力行為, 「性行為の強制」は拒否しているにもかか わらず性行為を無理強いされたり, 避妊をしないなどの行為, 「信頼関係の破綻」は嘘をつく, 隠し事をする, 自分のことを 信用しないなどの行為, 「性格への嫌悪」は意志の弱さなどの 自分が好ましく思わない相手の性格的特徵を表すような行為, 「第三者への迷惑行為」は自分以外の他者や友人に対して迷惑 となる行為であった。

多くの研究において DV を精神的暴力 (怒鳴る, 束縛, 馬 鹿にする, 無視など), 身体的暴力 (けがをさせる, 殴るなど), 性的暴力（性的行為の強要, 避妊に非協力など）に分けてい る。本研究で抽出されたカテゴリーがすべて，DV に当たる とは言い切れないが，本研究でも「身体的暴力」のカテゴリ 一が抽出され，「見下し」「姤妬・束縛」「ないがしろ・放置」 「怒りをぶつける」「コントロール」などは精神的暴力に含まれ， 「性行為の強制」「性的行為の要求」が性的暴力に含まれると 考えられる。身体的暴力に比べて精神的暴力に含まれるカテ ゴリーは多く, 実際に行われている精神的暴力は多種多様で あることが推測される。そのため, 精神的暴力は比較的 DV と認識されにくく，見過ごされやすいのではないかと考えら れた。

\begin{tabular}{|c|c|}
\hline カテゴリー名 & 記述数 \\
\hline 見下し & $14(10 \%)$ \\
\hline 浮気 & $14(10 \%)$ \\
\hline 嫉妬・束縛 & $14(10 \%)$ \\
\hline ないがしろ・放置 & $12(9 \%)$ \\
\hline 性的行為の要求 & $11(8 \%)$ \\
\hline 第三者への気のある素振り & $10(7 \%)$ \\
\hline 約束の反故 & $8(6 \%)$ \\
\hline 怒りをぶつける & $7(5 \%)$ \\
\hline 趣味・主張の押し付け & $7(5 \%)$ \\
\hline コントロール & $7(5 \%)$ \\
\hline 関係解消 & $7(5 \%)$ \\
\hline 身体的暴力 & $6(4 \%)$ \\
\hline 性行為の強制 & $5(4 \%)$ \\
\hline 信頼関係の破綻 & $5(4 \%)$ \\
\hline 性格への嫌悪 & $5(4 \%)$ \\
\hline 第三者への迷惑行為 & $4(3 \%)$ \\
\hline その他 & $4(3 \%)$ \\
\hline 合計 & 140 \\
\hline
\end{tabular}

